\title{
Hydrogeochemical Assessment of Groundwater in Neyveli Basin, Cuddalore District, South India.
}

\author{
M.V.Prasanna ${ }^{1}$, S.Chidambaram ${ }^{2}$, G.Senthil Kumar $^{3}$ and AL.Ramanathan ${ }^{4}$, H.C. Nainwal ${ }^{5}$ \\ 1. School of Engineering and Science, Department of Applied Geology, Curtin University of Technology, Sarawak \\ Campus, CDT 250, 98009, Miri, SarawakMalaysia. \\ 2. Department of Earth Sciences, Annamalai University, Annamalai Nagar, India. \\ 3. Powertech Engineering LLC, Seeb, Sultanate of Oman. \\ 4. School of Environmental Sciences, Jawaharlal Nehru University, New Delhi, India. \\ 5. Department of Geology, Hemwati Nandan Bahuguna Garhwal University, India. \\ *Corresponding author email: geoprasanna@gmail.com
}

\begin{abstract}
In the light of progressive depletion of groundwater reservoir and water quality deterioration of the Neyveli basin, an investigation on dissolved major constituents in 25 groundwater samples was performed. The main objective was detection of processes for the geochemical assessment throughout the area. Neyveli aquifer is intensively inhabited during the last decenniums, leading to expansion of the residential and agricultural area. Besides semiaridity, rapid social and economic development stimulates greater demand for water, which is gradually fulfilled by groundwater extraction. Groundwaters of the study area are characterized by the dominance of $\mathrm{Na}+\mathrm{K}$ over $\mathrm{Ca}+\mathrm{Mg}$. $\mathrm{HCO}_{3}$ was found to be the dominant anion followed by $\mathrm{Cl}$ and $\mathrm{SO}_{4}$. High positive correlation were obtained among the following ions: $\mathrm{Ca}-\mathrm{Mg}, \mathrm{Cl}-$ $\mathrm{Ca}, \mathrm{Mg}, \mathrm{Na}-\mathrm{K}, \mathrm{HCO}_{3}-\mathrm{H}_{4} \mathrm{SiO}_{4}$ and F-K. The hydrochemical types in the area can be divided into two major groups: the first group includes mixed $\mathrm{Ca}-\mathrm{Mg}-\mathrm{Cl}$ and $\mathrm{Ca}-\mathrm{Cl}$ types. The second group comprises mixed Ca-Na- $\mathrm{HCO}_{3}$ and $\mathrm{Ca}-\mathrm{HCO}_{3}$ types. Most of the groundwater samples are within the permissible limit of WHO standard. Interpretation of data suggests that weathering, ion exchange reactions and evaporation to some extent are the dominant factors that determine the major ionic composition in the study area.
\end{abstract}

Keywords: Hydrogeochemistry, Weathering, Ion exchange, Saturation index, Neyveli basin. 


\section{Introduction}

In many areas, particularly in arid and semi-arid zones, groundwater quality limits to supply of potable fresh water. Hence, to utilize and protect valuable water resources effectively and predict the change in groundwater environments, it is necessary to understand the hydrochemical characteristics of the groundwater and its evolution under natural water circulation processes (Guendouz et al. 2003; Wen et al. 2005; Edmunds et al. 2006; Wen et al. 2008; Taheri Tizro and Voudouris 2008). In many coastal towns or cities, groundwater seems to be the only source of freshwater to meet domestic, agricultural and industrial needs. But groundwater is under constant threat of saline water intrusion, which seems to have become a worldwide concern (Amer 1995; Melloul and Goldenberg 1998; Ozler 2003; Terzic et al. 2008; Adepelumi et al. 2009).

The aquatic environment gets contaminated with a variety of pollutants generated from diverse sources (agriculture, industrial, and domestic). There has been tremendous increase in demand for fresh water due to population growth and intense agriculture activities. Land use for agricultural purpose in Neyveli region has increased alarmingly during last decenniums. Variation of groundwater quality in an area is a function of physicochemical parameters that are greatly influenced by geological formations and anthropogenic activities. Rao (2006a) has studied the nitrate pollution and its distribution in the groundwater of Srikakulam District, Andhra Pradesh, India. Joseph Richmond Fianko et al (2009) have studied the various sources of contaminants as well assess the physical and chemical quality of the groundwater in Tema District, Ghana. Mohsen jalali (2010) has reported the major hydrogeochemical processes that control the observed groundwater chemistry in the Alisadr, Hamadan, western Iran. Earlier studies reported the importance of hydrogeochemical studies of groundwater in a particular region (Sikdar et al. 2001; Apodaca et al. 2002; Tesoriero et al. 2004; Moller at al. 2007).

Neyveli basin lies within one of the semi-arid areas in India representing the south eastern part of Tamilnadu state. Water resources in such areas are mainly derived from groundwater and infrequent surface runoff, where water conservation projects are applied. In Cuddalore district, groundwater is considered as a major source of fresh water that is used in different purposes. It is currently exploited for two main reasons: (1) Neyveli open cast mining of Lignite requires heavy pumping at the rate of $9,000-10,000 \mathrm{~m}^{3} \mathrm{hr}^{-1}$ as water table condition 
has to be brought down below the level of mining (Anandhan 2005). (2) Water from the Veeranam Lake is supplied through transmission line to Chennai city. To augment the supply during summer season, 48 deep bore wells were drilled and operations are done alternatively to pump the groundwater from deep aquifer and the pumped water is connected to the New Veeranam Scheme (NVS) pipelines (Mohan Viswanathan Prasanna et al. 2009).

The Neyveli basin has met the total water requirement of the region for agriculture, industry (thermal power plant), drinking water and other miscellaneous uses. Pumping for strata depressurization has been a continuous process by Neyveli Lignite Corporation (NLC) for the last five decades. Detailed analysis of the pumping scenarios at the NLC mines revealed that optimal pumping for mining lies at around 170 (million cubic metres per annum) MCM/annum. Extraction from the Neyveli basin by NLC for depressuization of the mines and use by the thermal plants and the township is around $130 \mathrm{MCM}$ /annum. Groundwater extractions by other agencies for purposes like irrigation, drinking water for towns and villages and industrial use totals $110 \mathrm{MCM}$ /annum (NLC 1970-2007). The latter represents the most important renewable water resource in Cuddalore district, which is used for irrigation and domestic purposes and drinking in many areas. The increasing exploitation due to farming frequently causes deterioration in water quality. Therefore, variations in natural and human activities reflect spatial variations in the hydrochemical parameters of the groundwater. The difference of dissolved ions concentration in groundwater are generally, governed by lithology, velocity and quantity of groundwater flow, nature of geochemical reactions, solubility of salts and human activities (Karanth 1997; Bhatt and Salakani 1996). Appropriateness quantity and quality of groundwater become a more crucial alternative resource to meet the drastic increase in social and agricultural development and to avoid the expected deterioration of groundwater quality due to heavy abstraction for miscellaneous uses.

Some of the previous studies carried out in Neyveli basin focused on groundwater control techniques for safe exploitation of the Neyveli Lignite deposit (Anandan et al. 2010a), delineation of recharge area and artificial recharge studies (Anandan et al. 2010b) and groundwater basin management (Ravi Kumar et al. 2010). Hence, it is apparent that the hydrogeochemical processes that control the groundwater chemistry of the basin have not been studied in great deal. Hence, the present work was carried out with the major objective of identifying the major hydrogeochemical processes that are responsible for groundwater 
chemistry in the study area. Assessment of groundwater quality for various purposes was also carried out. This kind of investigation will help to create suitable management plans to protect aquifer as well as remedial measures for contaminated groundwater by natural and manmade activities.

\section{Study area}

Neyveli basin is located in Cuddalore district of Tamilnadu, South India. The area is located between the geographical coordinates, latitudes of $11^{\circ} 21^{\prime}-11^{\circ} 45^{\prime} \mathrm{N}$ and between longitudes of $79^{\circ} 30^{\prime}-79^{\circ} 54^{\prime} \mathrm{E}$ (Fig.1). The Neyveli hydrogeological basin is traversed with multiple aquifers and covers an area of about $3,500 \mathrm{~km}^{2}$. Relative humidity of the area was recorded in the eastern part of the district i.e., at Cuddalore ranges between 60 and 83\%, whereas in the western part of the district i.e., at Lekkur ranges between 46.73 and $71.12 \%$. Higher rates of relative humidity are observed during the months of northeast monsoon period i.e., from October-November-December, where as lower rates are observed during the summer months of April and May. The 70 years average annual rainfall of the district is $1160 \mathrm{~mm}$. More than $50 \%$ of the rainfall occurs during North - East Monsoon. About 30\% of the rainfall was recorded during southeast monsoon and the balance from January to May (CGWB 1997). In urban area, the total population is 562,167 and rural population is $1,560,592$. The density of population is 579 persons per. sq. $\mathrm{km}$.

The Neyveli area can be broadly divided into four physiographic divisions: two that are relatively high in the northwest and central portion, and the Gadila-Ponniyar and VellarManimuktha Nadhi alluvial plains. The north-western high land lies in the western part of Neyveli passing between Senthanadu and Virdhachalam in a northeast-southwest direction. The elevation ranges between 30 and $100 \mathrm{~m}$ above mean sea level. The central high area stretches roughly north-northeast to south-southwest in the center of the Neyveli field (Ravi Kumar et al. 2010).

The general stratigraphy of the study area is shown in Table 1. The aquifer sands of this huge basin and the associated formations (including the lignite), which belong to the Upper Miocene age of the Tertiary era (Anandan et al. 2010a). In the mines area, the typical stratigraphical sequence of the basin consists of an uppermost layer of 2-3 m of topsoil (lateritic loam) underlain by $40-50 \mathrm{~m}$ of argillaceous sandstone. The sandstone is underlain by a 
discontinuous seam of white sandy clay (1-2 m thick). The sandy clay is sometimes underlain by 2-10 $\mathrm{m}$ of semi-confined sand. Below this is the lignite seam, which ranges from 12 to $20 \mathrm{~m}$ in thickness. The lignite is generally underlain by a seam of ball clay $1-2 \mathrm{~m}$ thick. This is underlain by a confined sand formation that is about $400 \mathrm{~m}$ thick, which is the main aquifer of the basin. Clay seams ranging in thickness from 0.50 to $3.0 \mathrm{~m}$ occur within the aquifer formation.

The study area is underlined by the various geological formations ranging in age from Mio-pliocene to Recent sediments. The lithology of the study area (Fig. 2) has two stratigraphic units as follows: (1) Tertiary Unit, Argillaceous sandstone, pebble bearing grits, clays (variegated) with lignite seams and pebble beds, (2) Quarternary Unit, soils, alluvium and coastal sands and laterite. There are three types of aquifers in this region viz., Phreatic aquifers, aquifer under semi - confined to confined conditions and alluvial aquifers. Phreatic aquifers found in the areas with the top Cuddalore sand stone. Along the river, shallow aquifers are available which are also under water table conditions. Generally, thickness of the top Cuddalore sand stone extends up to depth of about $100 \mathrm{~m}$ below ground level, where the alluvial formation along the river various from 20m to 40m below ground level (CGWB 1997). But these aquifers are very shallow. The confined aquifers are deep in nature. These aquifers available from $100 \mathrm{~m}$ to $450 \mathrm{~m}$ below ground level. Generally, yield from the shallow aquifers are less than deep aquifers.

\section{Methodology}

To assess the water chemistry, groundwater samples were collected during the period of February 2007 in the study area. Twenty five samples of groundwater were collected from bore wells. After 15-20 minutes of pumping, water samples were collected in polyethylene bottles (1 Liter). Then it was sealed and brought to laboratory for analysis and stored properly $\left(4^{\circ} \mathrm{C}\right)$ before analysis. The samples collected were analyzed for major cations like, $\mathrm{Ca}$ and $\mathrm{Mg}$ by Titrimetry, $\mathrm{Na}$ and $\mathrm{K}$ by Flame photometer (CL 378); anions, $\mathrm{Cl}$ and $\mathrm{HCO}_{3}$ by Titrimetry, $\mathrm{SO}_{4}, \mathrm{PO}_{4}$, and $\mathrm{H}_{4} \mathrm{SiO}_{4}$ by Spectrophotometer (SL 171 minispec) and Nitrate and Fluoride by ion electrodes. EC and $\mathrm{pH}$ were determined in the field using electrode (Eutech). The analyses were done by adopting standard procedures (APHA 1998). The analytical precision for the measurements of cations and anions is indicated by the ionic balance error, which was computed on the basis of 
ions expressed in milliequivalent per liter. The values were observed to be within a standard limit of $\pm 5 \%$ (Domenico and Schwartz 1998). All concentration values were expressed in milligram per liter (mg/l) unless otherwise indicated. In this study, correlation analyses were applied using Statistical Package of Social Studies (SPSS) version 10.

\section{Results and Discussion}

\section{Major ions chemistry}

Hydrochemical characteristics of groundwater in the study area are summarized in Table 2. The $\mathrm{pH}$ of groundwater varies within a range $(6.6-8.1)$, which elaborates a trend of alkaline chemical reaction within the groundwater system. The EC varies from 354 to $1596 \mu \mathrm{s} / \mathrm{cm}$ with an average of $827.7 \mu \mathrm{s} / \mathrm{cm}$. Chemical data shows that 13 samples are fresh water $(<500 \mu \mathrm{s} / \mathrm{cm})$, while 12 samples are marginal waters $(500-1500 \mu \mathrm{s} / \mathrm{cm})$ in the study area. The TDS concentrations of the groundwater range from 247.8 to $1117.2 \mathrm{mg} / \mathrm{l}$ with an average value of $571.17 \mathrm{mg} / \mathrm{l}$. The concentrations of TDS in most groundwater samples are $<1000 \mathrm{mg} / \mathrm{l}$, i.e. fresh water. The relative concentrations of the ions occur in the order of $\mathrm{Na}>\mathrm{Ca}>\mathrm{K}>\mathrm{Mg}$ and $\mathrm{HCO}_{3}>\mathrm{Cl}>\mathrm{SO}_{4}$. The concentrations of major dissolved constituents were also quite variable. Such wide range of ionic concentrations also indicates the involvement of several hydrochemical processes influencing the water quality. Correlation between ions was carried out using correlation coefficient analysis (Chidambaram et al. 2007). Table 3 shows the correlation coefficients between the major ions in groundwater. High positive correlation $(>0.5)$ has been obtained between: $\mathrm{Ca}-\mathrm{Mg}, \mathrm{Cl}-\mathrm{Ca}, \mathrm{Mg}, \mathrm{Na}-\mathrm{K}, \mathrm{HCO}_{3}-\mathrm{H}_{4} \mathrm{SiO}_{4}$ and $\mathrm{F}-\mathrm{K}$ indicating the predominance of chemical weathering along with leaching of secondary salts. $\mathrm{SO}_{4}$ and $\mathrm{NO}_{3}$ develop poor correlation with all the ions indicating the anthropogenic impact from agricultural practices.

\section{Groundwater types}

Ionic concentrations were plotted in a piper diagram to evaluate the geochemical characteristics of the sampled groundwater. The projection of the points in the central diamondshaped revealed the heterogeneity of the groundwater chemical composition in this area. On the basis of this diagram (Fig. 3), it is clear that in all the waters, alkali earth elements $(\mathrm{Ca}+\mathrm{Mg})$ are higher than alkali elements $(\mathrm{Na}+\mathrm{K})$. The abundance of the alkali earth elements is attributed to 
dissolution of $\mathrm{Ca}$ and $\mathrm{Mg}$-rich silicate minerals in the aquifer matrix. The removal of $\mathrm{Ca}$, through the precipitation of carbonate minerals, may cause a disturbance in chemical equilibrium, resulting in the dissolution of minerals containing calcium such as calcite and gypsum (Freeze and Cherry 1979). These minerals precipitated from irrigated water under the influence of high rate of evaporation and evapotranspiration. Weathering of rocks results in the release of sodium and potassium from K-feldspars and plagioclase into the environment, even though potassium has low mobility and remains associated with clay minerals. On the other hand, the position of the groundwater in the anions triangle indicates dominance of the $\mathrm{Cl}$ and $\mathrm{HCO}_{3}$, but a complete absence of sulfate in the waters. The distribution of points in the cations triangle reveals that majority of samples do not categorize in any dominant cation type.

As a consequence two types of groundwater can be chemically distinguished (Fig. 3). In the first group, the position of data represents mixed $\mathrm{Ca}-\mathrm{Mg}-\mathrm{Cl}$ and $\mathrm{Ca}-\mathrm{Cl}$ types. The $\mathrm{Cl}$ is the major anions and $\mathrm{Ca}+\mathrm{Mg}$ are major cations in this groundwater. This facies is characterized by low concentration of $\mathrm{HCO}_{3}$ and relatively higher concentration of $\mathrm{Cl}$ and $\mathrm{Ca}$, which are mainly distributed among the marine sediments, occurs in the intermediate zone of groundwater discharge area.

In the second group, the position of data represents mixed $\mathrm{Ca}-\mathrm{Na}-\mathrm{HCO}_{3}$ and $\mathrm{Ca}-\mathrm{HCO}_{3}$ types. The $\mathrm{HCO}_{3}$ is the major anions and $\mathrm{Ca}$ is the major cations in this groundwater. This type of water occurs during rapid flow through times, which results in low ionic concentrations during high recharge in shallow zones. $\mathrm{Na}$ and $\mathrm{HCO}_{3}$ concentrations come mainly from weathering of alkali-feldspars from rocks related with the recharge areas.

\section{Geochemical evolution}

The results from the chemical analyses were used to identify the geochemical processes and mechanisms in the Neyveli basin. The Na-Cl relationship has often been used to identify the mechanisms to acquire salinity and saline intrusions in semi-arid/arid regions (Sami 1992). In general, evaporation causes an increase in concentrations of all species in water. If the evaporation process is dominant, and no minerals species are precipitated, the $\mathrm{Na}-\mathrm{Cl}$ ratio is unchanged (Jankowski and Acworth 1997). Hence the plot $\mathrm{Na} / \mathrm{Cl}$ versus $\mathrm{Cl}$ would give a horizontal line, which would indicate concentration by evaporation and transpiration (Fig. 4a). If 
halite dissolution is responsible for sodium, the $\mathrm{Na} / \mathrm{Cl}$ molar ratio is approximately one, whereas a ratio $>1$, it is typically interpreted that $\mathrm{Na}$ is released from a silicate weathering reaction (Meybeck 1987). In the present study area, generally ranges from 0.3 to 2.1 with an average of 0.8. When $\mathrm{Na}$ is plotted against $\mathrm{Cl}$ (Fig. 4b), most of the samples lie below the 1:1 trend line show excess $\mathrm{Cl}$ highlights additional geochemical process. The high $\mathrm{Na} / \mathrm{Cl}$ ratios are probably controlled by water-rock interaction, most likely by feldspar weathering. The high $\mathrm{K} / \mathrm{Cl}$ ratios $(>0.2)$ are associated with the dissolution of K-feldspar that suggests its weathering (Fig 4c).

The study of the $\mathrm{Ca} / \mathrm{Mg}$ ratio of groundwater from this area suggests that greater calcite contribution (Maya and Loucks 1995), that is, if the ratio $\mathrm{Ca} / \mathrm{Mg}=1$, dissolution of dolomite should occur, whereas a higher ratio is indicative of greater calcite contribution. Katz et al. (1998) also explained that the higher $\mathrm{Ca} / \mathrm{Mg}$ molar ratio $(>2)$ is indicative of dissolution of silicate minerals, which contribute calcium and magnesium to groundwater. The groundwater samples have a ratio between 1 and 2 indicating the dissolution of calcite (Fig. 4d). The molar ratio is generally less than or equal to 1 in the study area and some of them have this ratio more than 1, which indicates that the dissolution of dolomite and calcite are the dominant geochemical processes followed by the dissolution of silicate minerals.

Calcium and magnesium are the dominant cations present in groundwater next to sodium in this region. Similarly, bicarbonate is also present in considerable amounts. Carbonate-rich rocks such as crystalline limestone, dolomitic limestone, calc-granulite and kankar (lime-rich weathered mantle overlies carbonate rocks) are the major sources for carbonate weathering. The available carbonates in these rocks might have been dissolved and added to the groundwater system during irrigation, rainfall infiltration and groundwater movement.

In $\mathrm{Ca}+\mathrm{Mg}$ vs $\mathrm{HCO}_{3}+\mathrm{SO}_{4}$ scatter diagram (Fig. 4e), the points falling along the equiline $\left(\mathrm{Ca}+\mathrm{Mg}=\mathrm{HCO}_{3}+\mathrm{SO}_{4}\right)$ suggest that these ions have resulted from weathering of carbonates and sulphate minerals (Datta and Tyagi 1996). Moreover, if the $\mathrm{Ca}$ and $\mathrm{Mg}$ solely originated from carbonate and silicate weathering, these should be balanced by the alkalinity alone. However, most of the points are placed in the $\mathrm{Ca}+\mathrm{Mg}$ side, which indicates excess calcium and magnesium derived from other process such as reverse ion exchange reactions. The plot of $\mathrm{Ca}+\mathrm{Mg}$ versus $\mathrm{Cl}$ 
(Fig. 4f) indicates that concentrations of the two items are roughly the same as $\mathrm{Ca}$ and $\mathrm{Mg}$ do not increase with increasing salinity that could be the indication of reverse-ion exchange in the clay/weathered layer.

The $\mathrm{Ca}+\mathrm{Mg} / \mathrm{HCO}_{3}$ ratio is used to explain the sources of $\mathrm{Ca}$ and $\mathrm{Mg}$ in groundwater. As this ratio increases with salinity, $\mathrm{Mg}$ and $\mathrm{Ca}$ are added to solution at a greater rate than $\mathrm{HCO}_{3}$. If $\mathrm{Mg}$ and $\mathrm{Ca}$ only originate from the dissolution of carbonates in the aquifer materials and from the dissolution of carbonates in the aquifer materials and from the weathering of accessory minerals, this ratio would be about 0.5 (Sami 1992). The plot of $\mathrm{Ca}+\mathrm{Mg}$ versus $\mathrm{HCO}_{3}$ in Fig. $4 \mathrm{~g}$ shows that most of the data fall above the 1:1 trend line, although some points approach this line. The low $\mathrm{Ca}+\mathrm{Mg} / \mathrm{HCO}_{3}$ ratio $(<0.5)$ could be the result of either $(\mathrm{Ca}+\mathrm{Mg})$ depletion by cation exchange or $\mathrm{HCO}_{3}$ enrichment (Fig. 4h). However high ratios cannot be attributed to $\mathrm{HCO}_{3}$ depletion; under the existing alkaline conditions, $\mathrm{HCO}_{3}$ does not form carbonic acid $\left(\mathrm{H}_{2} \mathrm{CO}_{3}\right)$ (Spears 1986). High ratio suggests that an excess of alkalinity in these waters is balanced by the alkalis $\mathrm{Na}$ and $\mathrm{K}$.

Molar Na/Ca ratios vary between 0.4 and 6, and some of them are of more than 2 (Fig. 4i). This indicated the reaction of silicate minerals and/or some cation exchange is occurring at the expense of some other cation (Wen et al. 2005).

\section{Mechanisms controlling the groundwater chemistry}

Reactions between groundwater and aquifer minerals have a significant role on water quality, which are also useful to understand the genesis of groundwater (Cederstorm 1946). Groundwater chemistry in the study region is regulated by diverse processes and mechanisms. Since the study region experiences dry and semiarid climatic condition, evaporation may also contribute in water chemistry in the study region. Hence, Gibbs plot is employed in this study to understand and differentiate the influences of rock-water interaction, evaporation and precipitation on water chemistry (Gibbs 1970). Fig. 5 illustrates that most of the groundwater samples fall in the water-rock interaction field and few samples plotted on evaporation zone, which suggests that the weathering of rocks primarily controls the major ion chemistry of groundwater in this region. 


\section{Evaporation}

Evaporation process is not only a common phenomenon in surface water but also in groundwater system. $\mathrm{Na} / \mathrm{Cl}$ ratio can be used to identify the evaporation process in groundwater. Evaporation will increase the concentration of total dissolved solids in groundwater, and the $\mathrm{Na} / \mathrm{Cl}$ ratio remains the same, and it is one of the good indicative factors of evaporation. If evaporation is the dominant process, $\mathrm{Na} / \mathrm{Cl}$ ratio should be constant when $\mathrm{EC}$ rises (Jankowski and Acworth 1997). The EC vs Na/Cl scatter diagram of the groundwater samples (Fig. 6) shows that the trend line is inclined, and $\mathrm{Na} / \mathrm{Cl}$ ratio decreases with increasing salinity (EC) which seems to be removal of sodium by ion exchange reaction. This observation indicates that evaporation may not be the major geochemical process controlling the chemistry of groundwater in this study region or ion exchange reaction dominating over evaporation. However, the Gibbs diagrams (Fig. 5) justify that evaporation is not a dominant process in this basin.

\section{Ion exchange}

Ion exchange is one of the important processes responsible for the concentration of ions in groundwater. Chloro-alkaline indices 1 and 2 (CAI 1 and CAI 2) calculated for the groundwater samples of the basin strongly suggest the occurrence of ion exchange process.

$$
\begin{aligned}
& \mathrm{CAI} 1=\mathrm{C} 1-\mathrm{Na}+\mathrm{K} / \mathrm{C} 1 \\
& \mathrm{CAI} 2=\mathrm{C} 1-\mathrm{Na}+\mathrm{K} / \mathrm{SO}_{4}+\mathrm{HCO}_{3}+\mathrm{CO}_{3}+\mathrm{NO}_{3}
\end{aligned}
$$

All values are expressed in meq/l

When there is an exchange between $\mathrm{Ca}$ or $\mathrm{Mg}$ in the groundwater with $\mathrm{Na}$ and $\mathrm{K}$ in the aquifer material, both the above indices are negative, and if there is a reverse ion exchange, then both these indices will be positive (Schoeller 1965, 1967). CAI 1 and CAI 2 values of the study area vary with respect to samples, but they are positive in most of the samples, and few samples show negative values. This observation indicates that reverse ion exchange is the dominant process in the groundwater, whereas normal ion exchange is also noticed in a very few wells during the study period. 


\section{Groundwater salinization}

Since the study area fall near to the coastal zone and intensively pumped coastal aquifers leads to possible salinization in the groundwater. Fig. 7 shows that $\mathrm{Na}, \mathrm{Ca}$ and $\mathrm{Mg}$ are enriched when compared to its ratio with $\mathrm{Cl}$ in seawater. The $\mathrm{Na}$ enrichment observed in Fig. 6a demonstrates that $\mathrm{Na}-\mathrm{Ca}$ exchange, which is common in coastal aquifers intruded by seawater (Andersen et al. 2005), depleting $\mathrm{Na}$ content, is not the main process occurring in this area. In that case, the enrichment observed for $\mathrm{Ca}$ (Fig. 7b) is probably due to calcite dissolution, followed by a $\mathrm{pH}$ increasing $\left(\mathrm{CaCO}_{3}+\mathrm{H} \mathrm{Ca}+\mathrm{HCO}_{3}\right)$. The lowest enrichment was observed for $\mathrm{SO}_{4}$ (Fig. 7d), which may be related to the sulphate reduction process (Appelo and Postman 2005).

\section{Groundwater Quality}

Both for drinking as well as irrigation purposes substantial amount of groundwater is being used in this area. Further agriculture is economically important in the study area and mostly covered by agricultural lands and residents. Hence, groundwater contamination by irrigation return flow, fertilizer and farm manure application, leaching of soil mineralized nitrogen, domestic sewage etc is also an important issue on groundwater contamination in the study area. The concentration of nitrate and chloride in the groundwater justify the effect of surface contamination sources. The nitrate concentration varies from 1 to $67.9 \mathrm{mg} / \mathrm{l}$ with an average of $18.9 \mathrm{mg} / \mathrm{l}$. However, four samples exceed WHO (2004) standard and are not fit for drinking, which may cause blue baby disease/methaemoglobinaemia in children and gastric carcinomas (Comly 1945; Gilly et al. 1984). Since most of the basin is intensively irrigated, higher concentration of nitrate in groundwater can be resulted from the agricultural activities (Subramani et al. 2005a). In Neyveli basin, most of the samples are within the permissible limits (WHO 2004) for all parameters except K. Higher concentration of K also implies the effect of surface contamination, especially irrigation return flow to the groundwater.

\section{Saturation Index (Dissolution and Deposition)}

Using the saturation index (SI) approach, it is possible to predict the subsurface mineralogy from groundwater data without collecting the samples of the solid phase and 
analyzing the mineralogy (Deutsch 1997). In the present study area, to determine the chemical equilibrium between minerals and waters, saturation indices of carbonate and silicate minerals were calculated using the following equation (Lloyd and Heathcode 1985)

$\mathrm{SI}=\log (\mathrm{IAP} / \mathrm{Ks})$

Where IAP is the ion activity product and Ks is the solubility product of the minerals.

The calculated values of SI for calcite, dolomite, aragonite and magnesite of the groundwater samples shows that the calcite and aragonite fall near saturated to over saturated state indicates precipitation takes place (Fig. 8). Given the semi-arid climate, this is likely to be a result of evaporation. But the SI values of dolomite and magnesite are less than zero which shows that it remains under saturation.

\section{Summary and Conclusions}

The results of this investigation provide an outline of the geochemical processes controlling the groundwater chemistry in the study area. The hydrochemical types in the area can be divided into two major groups. The first group includes mixed $\mathrm{Ca}-\mathrm{Mg}-\mathrm{Cl}$ and $\mathrm{Ca}-\mathrm{Cl}$ types, indicate the intermediate zone of groundwater discharge area. The second group comprises mixed $\mathrm{Ca}-\mathrm{Na}-\mathrm{HCO}_{3}$ and $\mathrm{Ca}-\mathrm{HCO}_{3}$ types, reveals the groundwater recharge area. The concentrations of TDS in most groundwater samples are $<1000 \mathrm{mg} / \mathrm{l}$, i.e. fresh water. The relative concentrations of the ions occur in the order of $\mathrm{Na}>\mathrm{Ca}>\mathrm{K}>\mathrm{Mg}$ and $\mathrm{HCO}_{3}>\mathrm{Cl}>\mathrm{SO}_{4}$. In the study area, rock weathering and ion exchange reactions are the major hydrogeochemical processes responsible for the concentration of major ions in groundwater. Higher concentration of nitrate in some groundwater can be resulted from the agricultural activities. Generally, most of the samples in the basin are within the permissible limits for all parameters except $\mathrm{K}$. The calcite and aragonite have high SI values indicates precipitation as the result of evaporation, whereas the dolomite and magnesite shows undersaturation state. The information presented in this paper will be useful for sustainable management of this important groundwater resource according to the water chemistry and enable planners and policymakers to evolve a strategy to solve similar problems elsewhere. 


\section{References}

Adepelumi A.A, Ako B.D, Ajayi T.R, Afolabi O, Omotoso E.J (2009) Delineation of saltwater intrusion into the freshwater aquifer of Lekki Peninsula, Lagos, Nigeria. Environmental Geology 56: 927-933.

Amer A.M (1995) Saltwater intrusion in coastal aquifers. Water Resource Management 2: 521529.

Anandan K.S, Sahay S.N, Karthikeyan (2010b) Delineation of recharge area and artificial recharge studies in the Neyveli Hydrogeological Basin. Mine Water Environment 29: 1422.

Anandhan K.S, Sahay S.N, Ramabadran T.K, Shiv Prasad S (2010a) Groundwater control techniques for safe exploitation of the Neyveli Lignite deposit, Cuddalore District, Tamilnadu, India. Mine Water Environment 29: 3-13.

Anandhan P (2005) Hydrogeochemical studies in and around Neyveli mining region, Tamilnadu, India. Ph.D Thesis, Department of Earth Sciences, Annamalai University, India. 189p.

Anderson M.S, Nyvang V, Jakobsen R, Postma D (2005) Geochemical processes and solute transport at the seawater/freshwater interface of a sand aquifer. Geochimica and Cosmochimica Acta 69: 3979-3994.

APHA (1998) Standard methods for the examination of water and waste water $\left(19^{\text {th }}\right.$ ed.). Washington, DC: American Public Health Association.

Apodaca L.E, Jeffrey B.B, Michelle C.S (2002) Water quality in shallow alluvial aquifers, Upper Colorado River Basin, Colorodo. Journal of the American Water Resources Association 38: $133-143$.

Appelo C.A.J, Postman D (2005) Geochemistry. Groundwater and Pollution (second edn.): Balkema, Rotterdam, 649p.

Bhatt K.B, Salakani S (1996) Hydrogeochemistry of the upper Ganges river, India. Journal of Geological Society of India 48: 171-182.

Cederstorm D.J (1946) Genesis of groundwater in the coastal plain of Virginia. Environmental Geology 41: 218-245. 
CGWB (1997) Groundwater resources and development prospects in South ArcotVallalar District, Tamilnadu. South Eastern Coastal Region, Chennai. (Unpublished Report).

Chidambaram S, Ramanathan AL, Prasanna M.V, Anandhan P, Srinivasamoorthy K, Vasudevan S (2007) Identification of hydrogeochemically active regimes in groundwaters of erode district, Tamilnadu-A statistical approach. Asian Journal of Water, Environment and Pollution 5(3): 93-102.

Comly H.H (1945) Cyanosis in infants caused by nitrates in well water. Journal of the American Medical Association 129: 12-114.

Datta P.S Tyagi S.K (1996) Major ion chemistry of groundwater in Delhi area: Chemical weathering processes and groundwater regime. Journal of the Geological Society of India 47: 179-188.

Deutsch WJ (1997) Groundwater geochemistry: fundamentals and application to contamination: CRC, Boca Raton.

Domenico P.A Schwartz F.W (1998) Physical and Chemical Hydrogeology, second ed. Wiley, New York, 506p.

Edmunds WM, Ma JZ, Aeschbach-Hertig W, Kipfer R, Darbyshire DPF (2006) Groundwater recharge history and hydrogeochemical evolution in the Minqin basin, North west China. Applied Geochemistry 21;2148-2170.

Freez R.A, Cherry J.A (1979) Groundwater. Prentice-Hall Inc.: Englewood Cliffs, NJ, 553p.

Gibbs R.J. (1970) Mechanisms controlling world water chemistry. Science Journal 170: 795-840.

Gilly G, Corrao G, Favilli S (1984) Concentrations of nitrates in drinking water and incidence of gastric carcinomas. First descriptive study of the Piemonate Region, Italy. The Science of the Total Environment 34: 35-37.

Guendouz A, Moulla AS, Edmunda WM, Zouari K, Shand P, Mamou A (2003) Hydrogeochemical and isotopic evolution of water in the complex terminal aquifer in the Algerian Sahara. Hydrogeology Journal 11: 483-495.

Jankowski J, Acworth RI (1997) Impact of depris-flow deposits on hydrogeochemical processes and the development of dryland salinity in the Yass River catchment, New South Wales. Australia Hydrogeology Journal 5(4): 71-88.

Joseph Richmond Fianko, Nartey Vincent K (2009) The hydrochemistry of groundwater in rural 
communities within the Tema District, Ghana. Environmental Monitoring Assessment. doi:10.1007/s10661-009-1125-0.

Karanth K.B (1997) Groundwater Assessment, Development and Management. McGraw-Hill Publishers, New Delhi.

Katz B.G, Gopalan T.B, Bullen T.D, Davis J.H (1998) Use of chemical and isotopic tracers to characterize the interaction between groundwater and surface water in mantled karst. Groundwater Journal 35: 1014-1028.

Lloyd JW, Heathcode JA (1985) Nature inorganic hydrochemistry in relation to groundwater. Oxford University Press: New York.

Maya AL, Loucks MD (1995) Solute and isotopic geochemistry and groundwater flow in the Central Wasatch Range, Utah. Journal of Hydrology 172: 31-59.

Melloul L.C, Goldenberg A.J (1998) Early-indicator signals of groundwater contamination: the case of seawater encroachment. Environmental Geology 33(4): 279-288.

Meybeck M (1987) Global chemical weathering of surficial rocks estimated from river dissolved loads. Am J Sci 287: 401-428.

Mohan Viswanathan Prasann., Chidambaram S, Shahul Hameed A, Srinivasamoorthy K (2009) Study of evaluation of groundwater in Gadilam basin using hydrogeochemical and isotope data. Environmental Monitoring Assessment 168: 63-90.

Mohsen Jalali (2010) Groundwater geochemistry in the Alisadr, Hamadan, western Iran. Environmental Monitoring Assessment 166:359-369.

Moller P, Rosenthal E, Geyer S, Guttman J, Dulski P, Rybakov M (2007) Hydrochemical processes in the lower Jordan valley and in the Dead Sea area. Chemical Geology 239: 2749.

NLC (1970-2007) Various unpublished in-house technical reports on groundwater modeling of the Neyveli Basin. Neyveli Lignite Corporation Ltd, Neyveli, India.

Ozler H.M (2003) Hydrochemistry and salt-water intrusion in the Van aquifer, East Turkey. Environmental Geology 43: 759-775.

Rao N.S (2006a) Nitrate pollution and its distribution in the groundwater of Srikakulam district, Andhra Pradesh, India. Environmental Geology 49: 413-429. 
Ravi Kumar V, Sahay S.N, Periasamy, Shiv Prasad, Karthikeyan S (2010) Groundwater basin management at the Neyveli Lignite Mines. Mine Water Environment 29: 23-28.

Sami K (1992) Recharge mechanisms and geochemical processes in a semi-arid sedimentary basin, Eastern Cape, South Africa. Journal of Hydrology 139: 27-48.

Schoeller H (1965) Qualitative evaluation of groundwater resources. In methods and techniques of groundwater investigations and development (pp. 54-83): UNESCO.

Schoeller H (1967) Geochemistry of groundwater-an international guide for research and practice (Chap.15, pp. 1-18): UNESCO.

Sikdar P.K, Sarkar S.S, Palcoudhury S (2001) Geochemical evolution of groundwater in the quaternary aquifer of Calcutta and Howrah, India. Journal of Asian Earth Sciences 19:579594.

Spears DA (1986) Mineralogical control of the chemical evolution of groundwater. In: Trudgill St (ed) Solute processes: Wiley, Chichester, UK, 512p.

Subramani T, Elango L, Damodaraswamy S.R (2005a) Groundwater quality and its suitability for drinking and agricultural use in Chithar River basin, Tamilnadu, India. Journal of Environmental Geology 47: 1099-1110.

Taheri Tizro A, Voudouris KS (2008). Groundwater quality in the semi-arid region of the Chahardouly basin, West Iran. Hydrological process 22: 3066-3078.

Terzic J, Markovic T, Pekas Z (2008) Influence of sea-water intrusion and agricultural production on the Blato Aquifer, Island of Korcula, Croatia. Environmental Geology 54: 719-729.

Tesoriero A.J, Spruill T.B, Eimers L (2004) Geochemistry of shallow groundwater in coastal plain environments in the southeastern United States: Implication for aquifer susceptibility. Applied Geochemistry 19: 1471-1482.

Wen X, Wu Y, Su J, Zhang Y, Liu F (2005) Hydrochemical characteristics and salinity of groundwater in the Ejina basin, northwestern China. Environmental Geology 48: 665-675.

Wen XH, Wu YQ, Wu J (2008) Hydrochemical characteristics of groundwater in the Zhangye basin, northwestern China. Environmental Geology 55: 1713-1724.

WHO (World Health Ornanisation) (2004). Guidelines for drinking water quality; Third edition, Volume 1 Recommendations: Geneva, 515p. 
Table 1 Geological Succession of the study area

\begin{tabular}{|llll|}
\hline Era & Age & Formation & \multicolumn{1}{c|}{ Lithology } \\
Quaternary & $\begin{array}{l}\text { Recent to } \\
\text { Sub- Recent }\end{array}$ & $\begin{array}{l}\text { Alluviam \& } \\
\text { Laterite }\end{array}$ & $\begin{array}{l}\text { Soils,alluviam and coastal } \\
\text { sand,clays, kankar and } \\
\text { Laterite }\end{array}$ \\
\hline Tertiary & Mio-pliocene & $\begin{array}{l}\text { Cuddalore- } \\
\text { Sandstones }\end{array}$ & $\begin{array}{l}\text { Sandstone- Argillaceous and } \\
\text { pebble bearing grits, clays } \\
\text { (Variegated) with lignite } \\
\end{array}$ \\
& & Seams and pebble beds. \\
\hline
\end{tabular}

Source: CGWB 1997 
Table 2 Chemical summary of groundwater in the study area.

\begin{tabular}{|c|r|r|r|r|}
\hline Parameters & Minimum & Maximum & Average & $\begin{array}{c}\text { Standard } \\
\text { deviation }\end{array}$ \\
\hline $\mathbf{p H}$ & 6.60 & 8.10 & 7.40 & 0.38 \\
\hline $\mathbf{E C ~}(\boldsymbol{\mu s} / \mathbf{c m})$ & 354.00 & 1596.00 & 827.74 & 358.77 \\
\hline $\mathbf{T D S}(\mathbf{m g} / \mathbf{l})$ & 247.80 & 1117.20 & 579.42 & 251.14 \\
\hline $\mathbf{C a}(\mathbf{m g} / \mathbf{l})$ & 26.90 & 116.65 & 63.48 & 24.13 \\
\hline $\mathbf{M g}(\mathbf{m g} / \mathbf{l})$ & 12.23 & 66.55 & 35.98 & 14.15 \\
\hline $\mathbf{N a}(\mathbf{m g} / \mathbf{l})$ & 26.00 & 127.00 & 65.81 & 24.05 \\
\hline $\mathbf{K}(\mathbf{m g} / \mathbf{l})$ & 15.00 & 76.00 & 42.26 & 15.95 \\
\hline $\mathbf{C l}(\mathbf{m g} / \mathbf{l})$ & 67.96 & 333.78 & 153.33 & 66.95 \\
\hline $\mathbf{H C O} \mathbf{3}(\mathbf{m g} / \mathbf{l})$ & 38.02 & 394.18 & 186.45 & 82.53 \\
\hline $\mathbf{S O}_{\mathbf{4}}(\mathbf{m g} / \mathbf{l})$ & 1.00 & 24.60 & 9.61 & 6.74 \\
\hline $\mathbf{P O}_{\mathbf{4}}(\mathbf{m g} / \mathbf{l})$ & 0.20 & 0.87 & 0.35 & 0.13 \\
\hline $\mathbf{H}_{\mathbf{4}} \mathbf{S i}_{\mathbf{4}} \mathbf{( m g / l )}$ & 8.24 & 41.33 & 21.36 & 8.88 \\
\hline $\mathbf{F}(\mathbf{m g} / \mathbf{l})$ & 0.03 & 0.81 & 0.24 & 0.19 \\
\hline $\mathbf{N O}_{\mathbf{3}}(\mathbf{m g} / \mathbf{l})$ & 0.99 & 67.90 & 18.95 & 19.87 \\
\hline
\end{tabular}


Table 3 Correlation coefficients between major ions in groundwater

\begin{tabular}{|c|c|c|c|c|c|c|c|c|c|c|c|c|}
\hline & $\mathrm{pH}$ & $\mathrm{EC}$ & $\mathrm{Ca}$ & $\mathrm{Mg}$ & $\mathrm{Na}$ & $\mathrm{K}$ & $\mathrm{Cl}$ & $\mathrm{HCO}_{3}$ & $\mathrm{SO}_{4}$ & $\mathrm{H}_{4} \mathrm{SiO}_{4}$ & $\mathrm{NO}_{3}$ & $\mathrm{~F}$ \\
\hline $\mathrm{pH}$ & 1.00 & & & & & & & & & & & \\
\hline $\mathrm{EC}$ & 0.04 & 1.00 & & & & & & & & & & \\
\hline $\mathrm{Ca}$ & -0.23 & 0.27 & 1.00 & & & & & & & & & \\
\hline $\mathrm{Mg}$ & -0.21 & 0.07 & $\mathbf{0 . 5 7}$ & 1.00 & & & & & & & & \\
\hline $\mathrm{Na}$ & 0.06 & -0.28 & -0.19 & -0.39 & 1.00 & & & & & & & \\
\hline $\mathrm{K}$ & 0.22 & -0.04 & -0.16 & -0.49 & $\mathbf{0 . 5 8}$ & 1.00 & & & & & & \\
\hline $\mathrm{Cl}$ & -0.17 & 0.35 & $\mathbf{0 . 6 6}$ & $\mathbf{0 . 4 6}$ & 0.03 & 0.06 & 1.00 & & & & & \\
\hline $\mathrm{HCO}_{3}$ & 0.28 & -0.41 & 0.07 & 0.10 & 0.41 & 0.10 & -0.28 & 1.00 & & & & \\
\hline $\mathrm{SO}_{4}$ & 0.19 & -0.41 & -0.05 & 0.34 & -0.09 & -0.10 & -0.16 & 0.39 & 1.00 & & & \\
\hline $\mathrm{H}_{4} \mathrm{SiO}_{4}$ & 0.21 & -0.18 & -0.13 & -0.06 & 0.26 & 0.06 & -0.31 & $\mathbf{0 . 4 6}$ & 0.20 & 1.00 & & \\
\hline $\mathrm{NO}_{3}$ & 0.04 & -0.12 & -0.12 & -0.33 & 0.23 & 0.23 & -0.12 & -0.17 & -0.12 & 0.22 & 1.00 & \\
\hline $\mathrm{F}$ & -0.12 & -0.14 & 0.24 & -0.05 & 0.33 & $\mathbf{0 . 4 6}$ & 0.37 & 0.35 & -0.06 & 0.01 & -0.28 & 1.00 \\
\hline
\end{tabular}



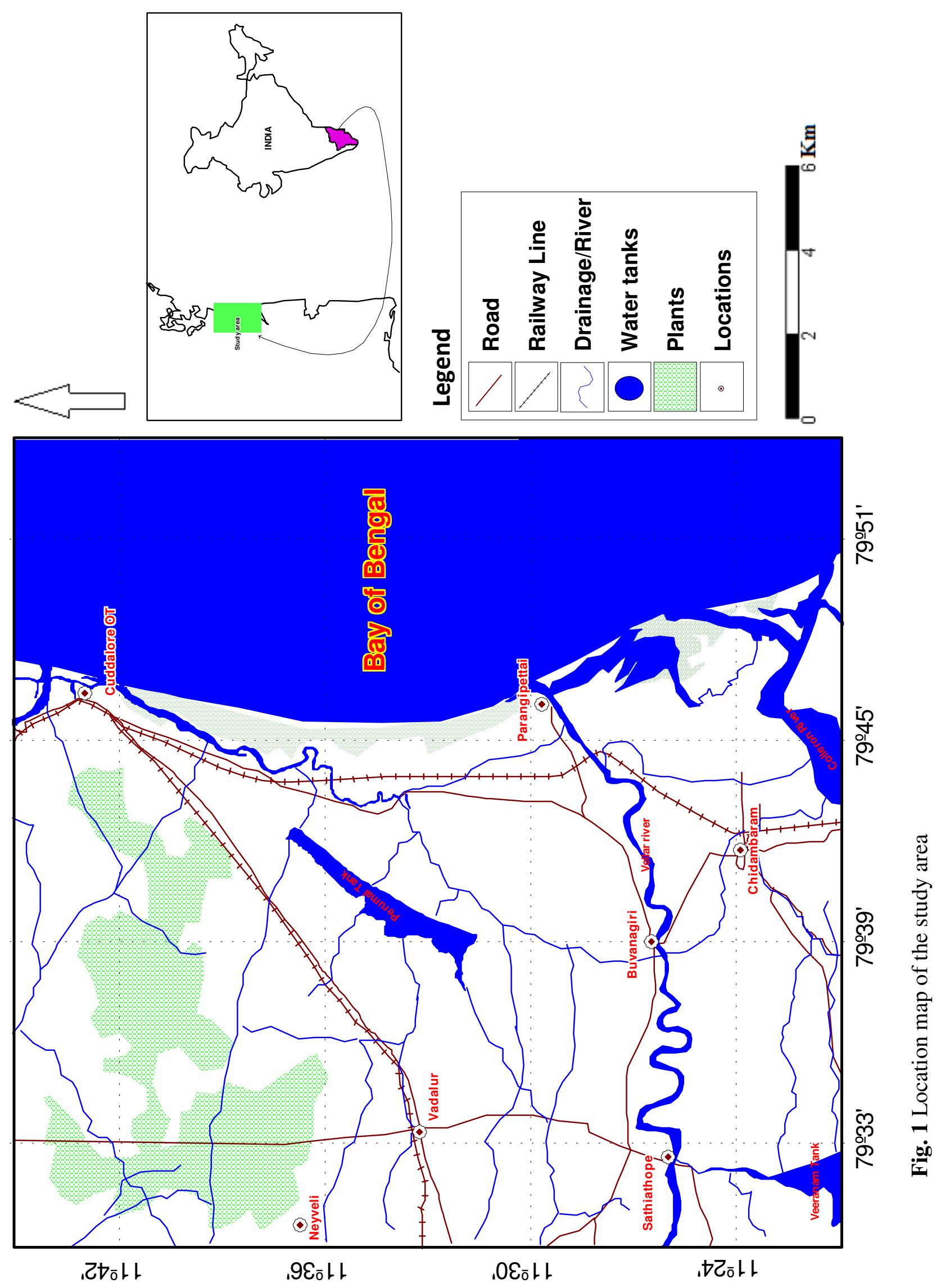

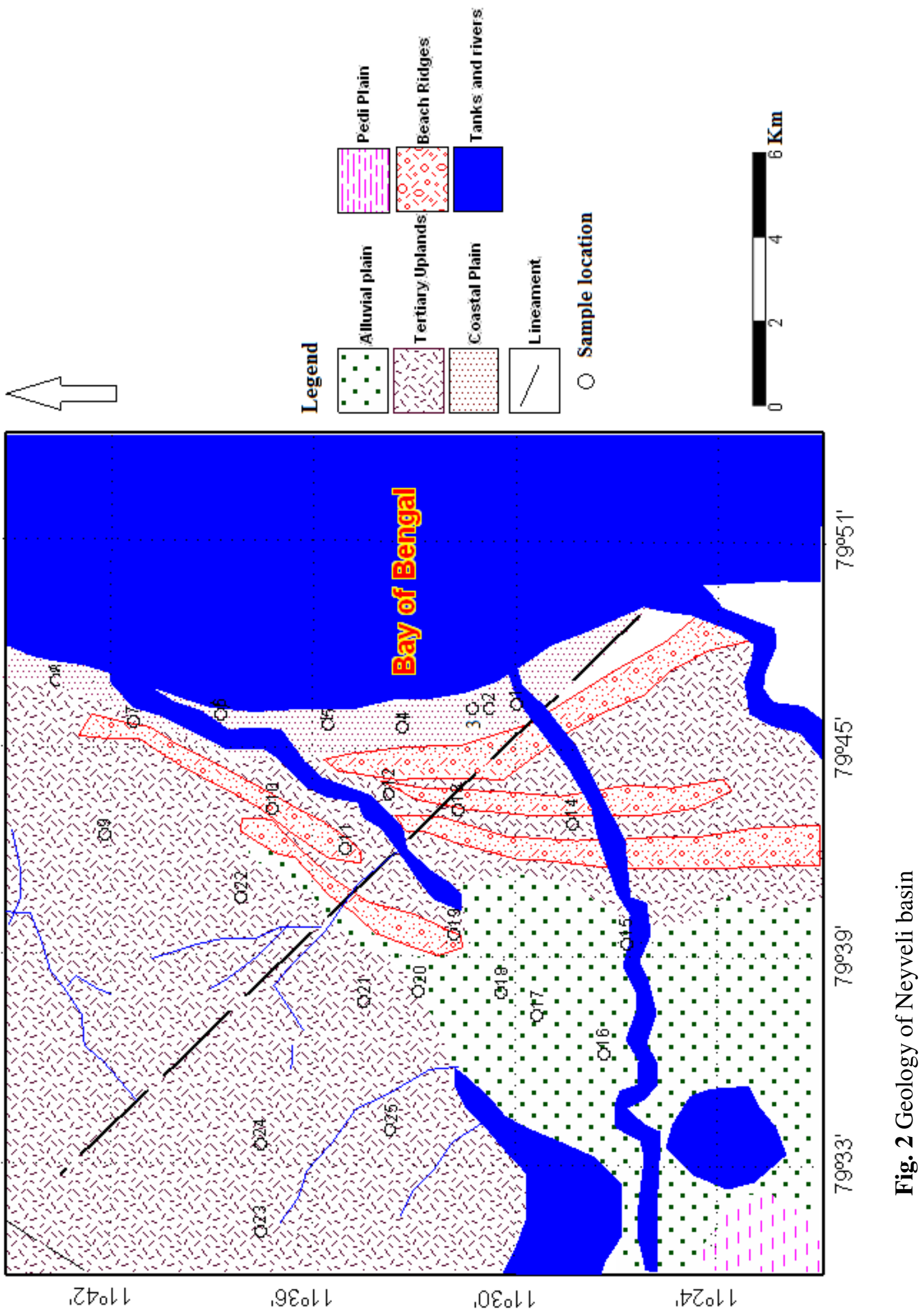


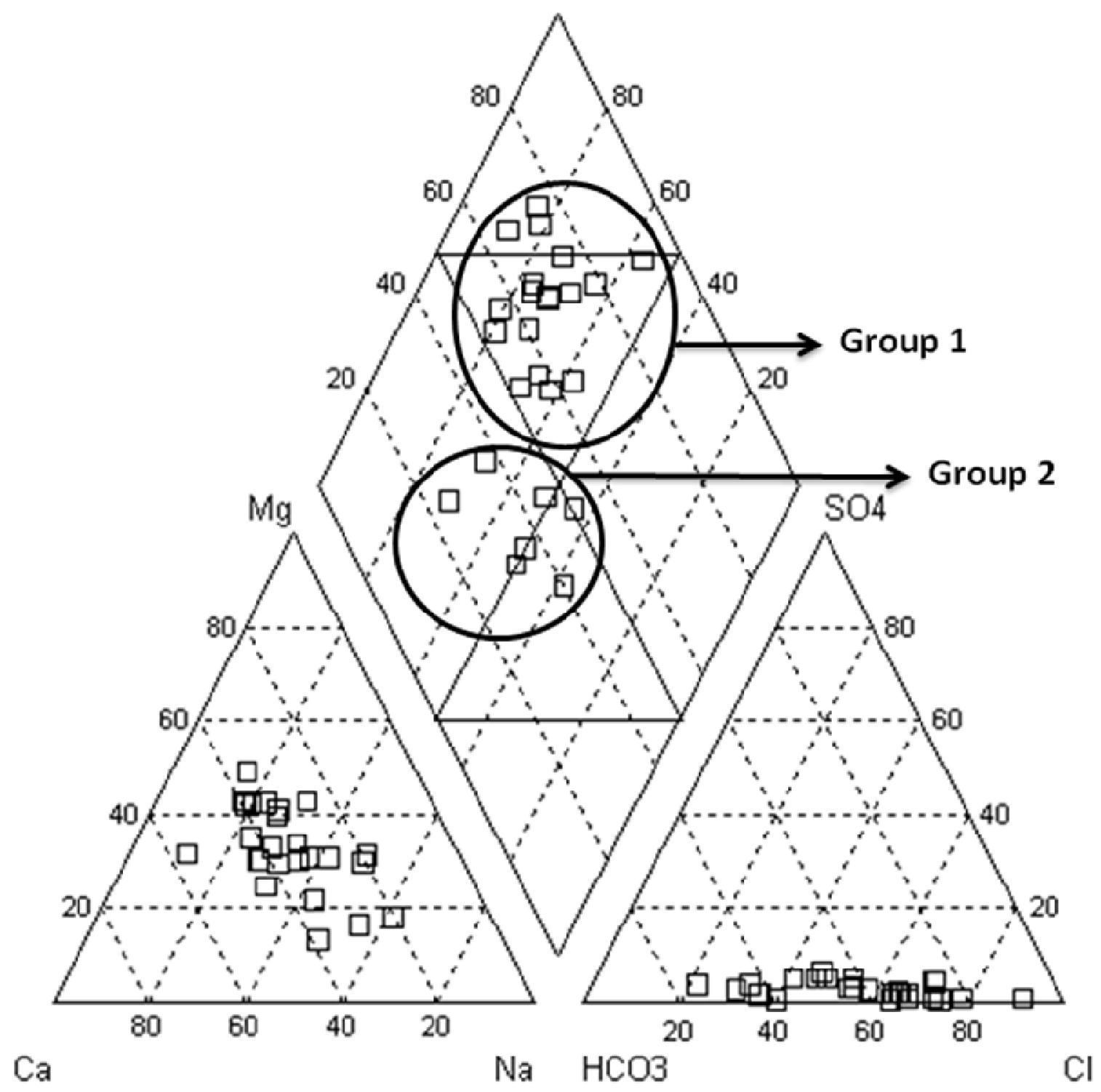

Fig. 3 Piper diagram 

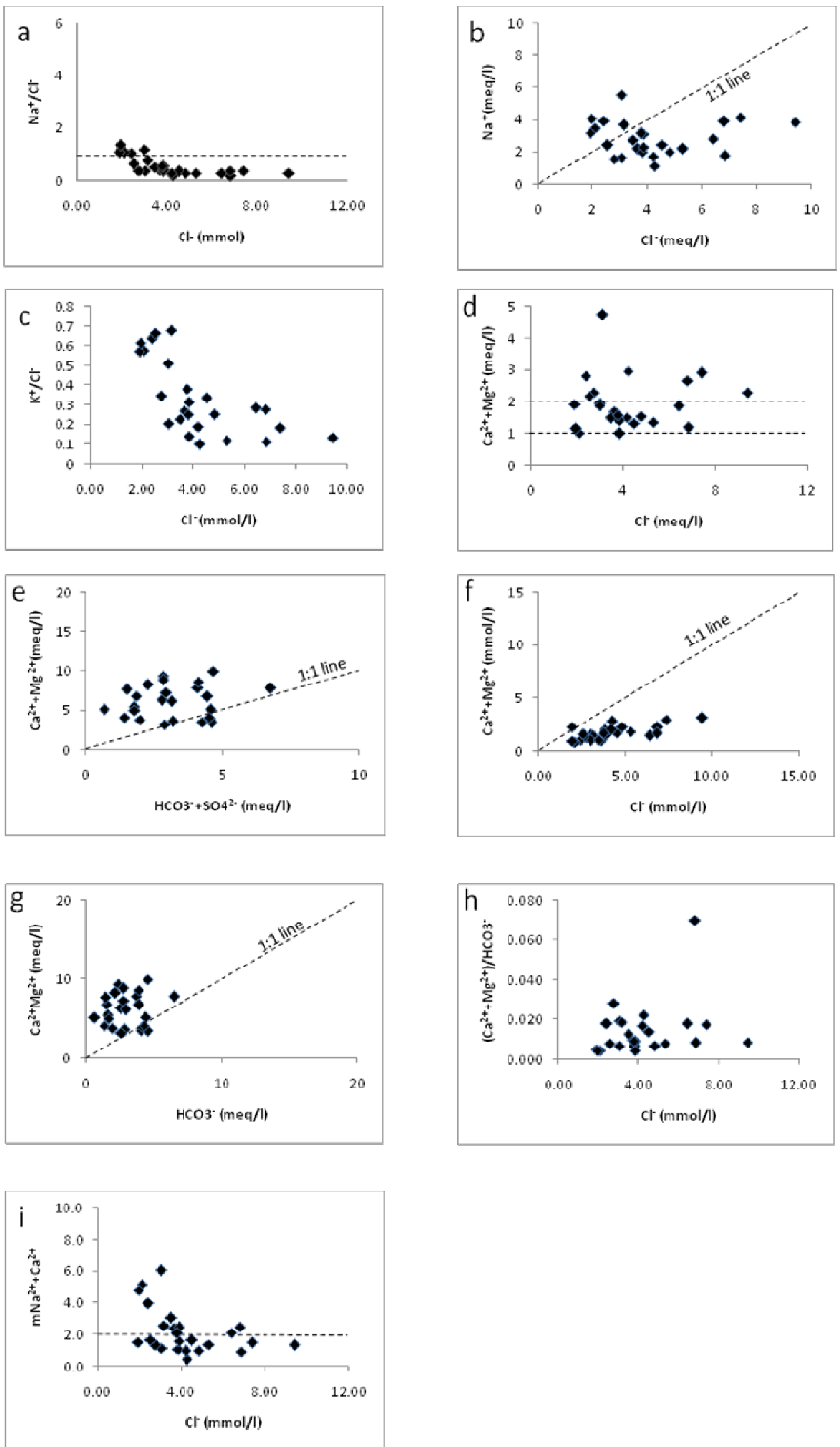

Fig. 4 Ions scatter diagram of groundwater in the study area 

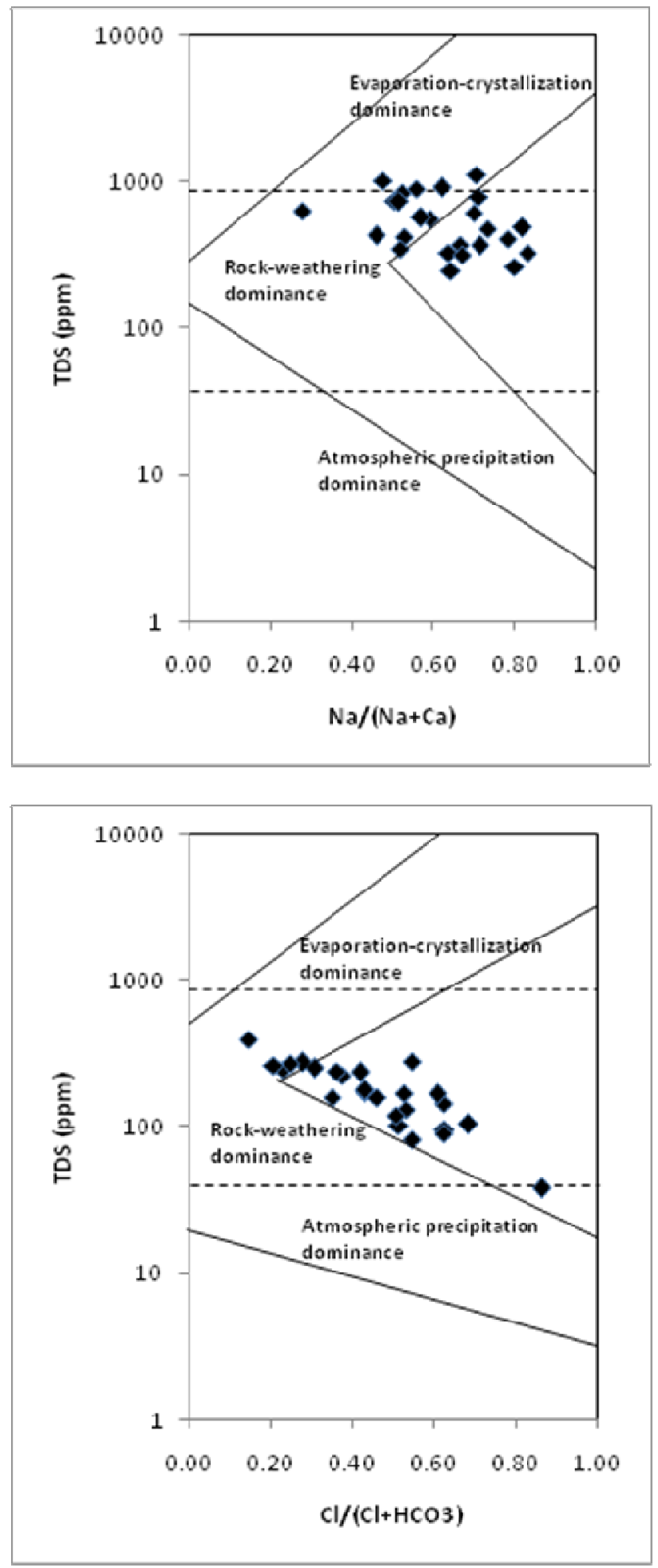

Fig. 5 Gibbs diagram, illustrating the mechanisms controlling the chemistry of groundwater samples 


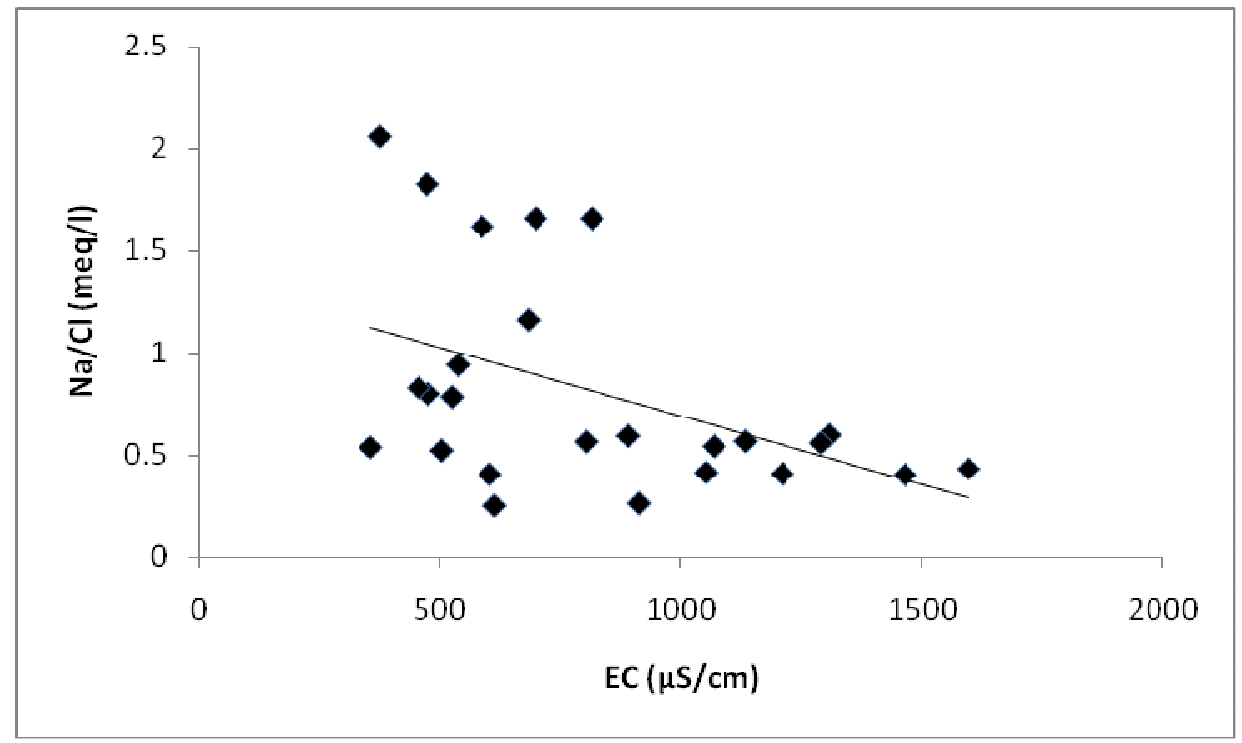

Fig. 6 Relationship between $\mathrm{EC}$ and $\mathrm{Na} / \mathrm{Cl}$ in the groundwater 

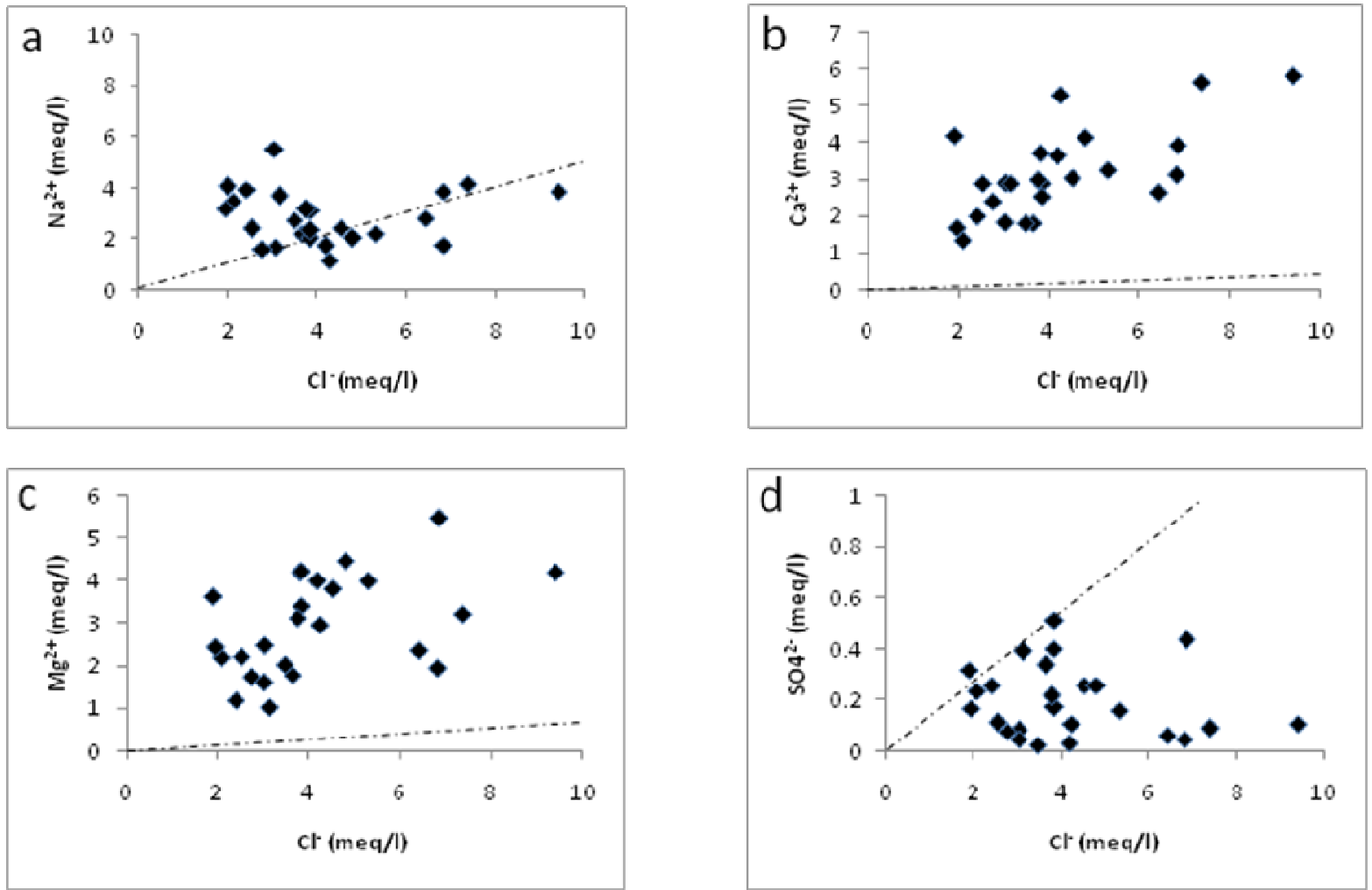

Fig. 7 Relationship between chloride and (a) $\mathrm{Na}$; (b) $\mathrm{Ca}$; (c) $\mathrm{Mg}$ and (d) $\mathrm{SO}_{4}$. Dashed line represents theoretical mixing line between freshwater and seawater 


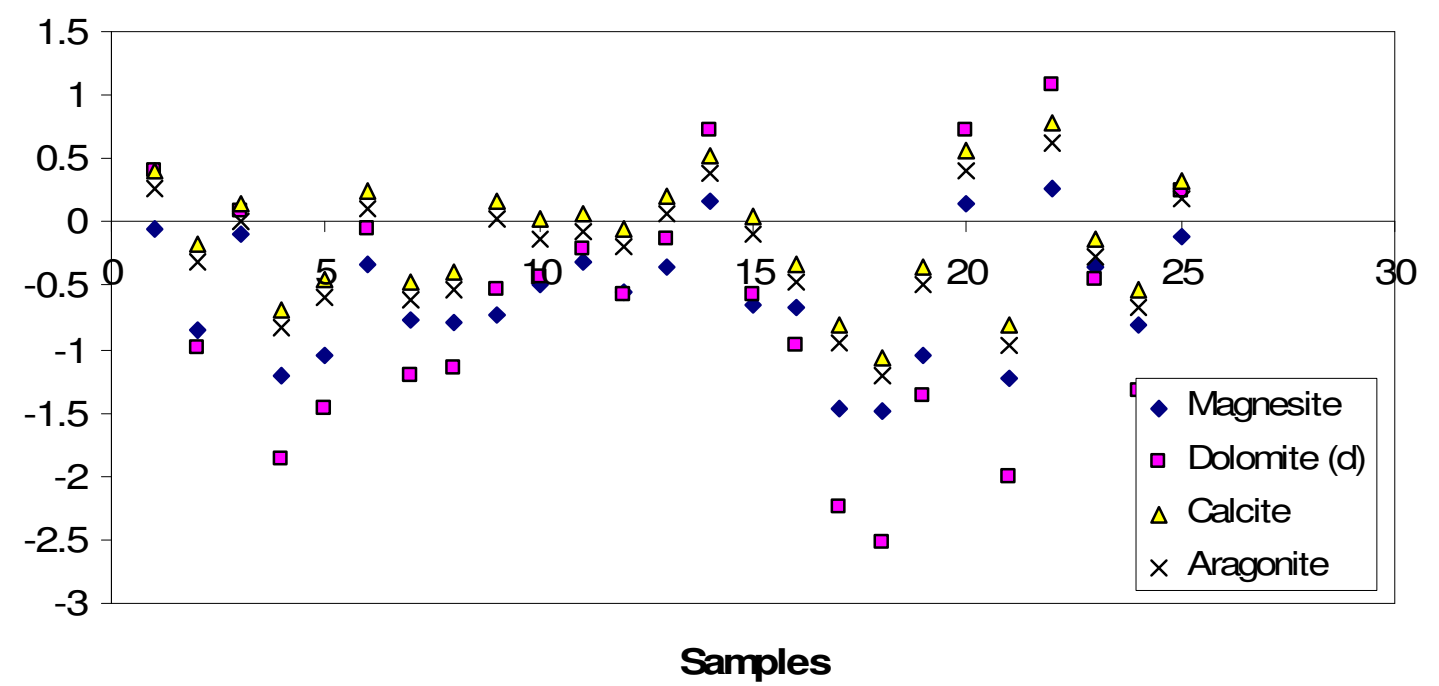

Fig. 8 Saturation index of Carbonate minerals 